\title{
Management of Arctic Marine Transportation: A Canadian Perspective ${ }^{1}$
}

\author{
D.M. McRAE ${ }^{2}$
}

(Received 15 October 1985; accepted in revised form 5 August 1986)

\begin{abstract}
Canada's interest in the management of the waters of the arctic archipelago has generally been expressed in terms of sovereignty. This term covers a range of interests including security, environmental protection and the protection of the way of life of northern communities, and resource exploitation. Three types of regimes can be proposed for the management of arctic marine transportation - a regime of free and open use with control over shipping remaining with the flag state of each vessel; a regime of shared jurisdiction under which arctic coastal states would jointly manage transportation throughout arctic waters, including the Northwest Passage; and a regime of coastal state jurisdiction, under which each coastal state would be responsible for all transportation in its adjacent waters. Under this last regime Canada would assume control over all marine transportation in the Northwest Passage. While a free and open use regime would favour transit interests, it would not deal adequately with environmental protection, the protection of northern communities or resource exploitation interests. In these latter matters there is an imbalance between the interests of Canada and the interests of other states concerned predominantly with transit. Canada has therefore laid the basis for complete coastal state control over the waters of the arctic archipelago with the drawing of straight baselines around these waters. This does not exclude a cooperative management regime; rather, it establishes a particular basis on which such a regime would operate. Thus, an effective management regime for marine transportation in the waters of the Canadian arctic archipelago will only be worked out once the question of jurisdiction over those waters is finally resolved.
\end{abstract}

Key words: arctic archipelago, sovereignty, Canada-U.S. relations, environmental protection, security, management, jurisdiction, Northwest Passage

RÉSUMÉ. L'intérêt que possède le Canada dans la gestion des eaux de l'archipel Arctique s'est souvent exprimé en termes de souveraineté. Ce terme recouvre toute une gamme d'intérêts y compris ceux rattachés à la sécurité, à la protection de l'environnement et à la préservation du mode de vie des communautés nordiques, ainsi qu'à l'exploitation des ressources. Il y a trois sortes de régimes qui peuvent s'appliquer à la gestion du transport maritime dans l'océan Arctique: un régime d'utilisation non restreinte où le contrôle de la navigation appartiendrait au pays dont le vaisseau arbore le drapeau; un régime de juridiction partagée en vertu duquel les Etats côtiers de l'Arctique gèreraient en commun le transport dans les eaux arctiques, y compris le passage du Nord-Ouest; et un régime de juridiction des Etats côtiers, en vertu duquel chaque Etat bordé par l'océan Arctique aurait la responsabilité de tout le transport dans ses eaux limitrophes. En vertu de ce dernier régime, le Canada aurait le contrôle de tout le transport maritime dans le passage du Nord-Ouest. Alors qu'un régime non restreint favoriserait les intérêts des transporteurs, il ne tiendrait pas compte de façon adéquate des intérêts reliés à la protection de l'environnement, à la préservation des communautés du Nord et à l'exploitation des ressources. En ce qui concerne ces intérêts, il y a un déséquilibre entre ceux du Canada et ceux d'autres pays dont la préoccupation principale est de faire transiter des marchandises dans ces eaux. Le Canada a donc jeté les bases pour un contrôle absolu par chaque Etat côtier sur les eaux de l'archipel Arctique, en traçant des lignes droites pour délimiter les zones. Cela n'exclut pas un régime de gestion coopérative, mais définit plutôt les principes particuliers selon lesquels un tel régime fonctionnerait. C'est ainsi qu'un régime de gestion efficace du transport maritime dans les eaux de l'archipel Arctique canadien ne pourra être mis en place que lorsqu'on aura enfin trouvé une solution au problème de la juridiction sur ces eaux.

Mots clés: archipel Arctique, souveraineté, relations entre le Canada et les Etats-Unis, protection de l'environnement, sécurité, gestion, juridiction, passage du Nord-Ouest

Traduit pour le journal par Nésida Loyer.

\section{INTRODUCTION}

This perspective on the issues raised by arctic marine transportation was prepared to provide a basis for discussion for the Arctic Policy Forum, rather than to provide a comprehensive account of arctic characteristics or to offer a detailed analysis of the problems. In order to establish a context for a consideration of approaches to resolving the complex and contentious issues arising out of marine transportation in arctic waters, it is necessary to outline Canadian interests and concerns in these waters generally. In the light of this background, alternative regimes for managing transportation in arctic waters will be set out, and their suitability for dealing with the fundamental issues will be considered.

The problems of transportation in Canadian and U.S. arctic waters arise in two quite distinct areas. First, there are the relatively open areas of the Arctic Ocean and the Beaufort Sea in the west and Baffin Bay and Davis Strait in the east. Secondly, there are the more enclosed waters of the Canadian arctic archipelago, in which the Northwest Passage is located. It is the special characteristics of the Canadian arctic archipelago and the sea/ice areas between its islands that lie at the root of the problem of the management of arctic marine transportation. If the Canadian arctic archipelago did not exist, both Canada and the United States would have similar jurisdictional regimes off their mainland coasts, and thus each would share a common problem applicable to its own separate area of jurisdiction. Canada would have marine transportation interests in arctic waters adjacent to the U.S. coasts and the U.S. would have marine transportation interests in waters adjacent to Canadian coasts. There would be a common interest in reconciling marine transportation issues with other issues in areas that would be geographically and environmentally similar. The existence of the Canadian arctic archipelago, however, makes the situation much more complex.

\section{CANADIAN ARCTIC ISSUES AND CONCERNS}

Canadian arctic aspirations have traditionally been expressed symbolically in terms of sovereignty. This was the purport of Senator Poirier's famous resolution in 1907, designed to confirm Canadian sovereignty over the "lands and islands situated in the north of the Dominion, and extending to the north

\footnotetext{
${ }^{1}$ This paper was prepared initially as a background paper for the Arctic Policy Forum held in October 1984

${ }^{2}$ Faculty of Law, University of British Columbia, Vancouver, British Columbia, Canada V6T IW5

(C) The Arctic Institute of North America
} 
pole." This statement is often taken as the origin of the sector theory, according to which the authority of arctic littoral states extends from their coasts to the North Pole. This desire for "sovereignty" was a remnant of the 19th-century desire to aggrandize territory and was based in part on a need to ensure a defined and secure northern border. But, as the claim to the islands of the Arctic achieved general recognition and acceptance, attention focused on the waters between the islands of the arctic archipelago. This brought a much greater awareness of the interrelationship between the waters and the land. Authority over the land dictated a predominant interest in the water and ice that adjoined the land. In other words, quite apart from 19th-century concepts of sovereignty and security, the littoral state in the Arctic was perceived by Canada at least to have an interest in the sea/ice that abutted the land. This relationship of arctic waters and arctic ice to the land appeared quite different from the relationship between land and sea that was the foundation of the traditional concept of authority over maritime areas - the 17th-century theory of free and open use of the seas.

It is important, therefore, when considering Canadian approaches to, or perspectives on, arctic marine transportation not to view the question simply in traditional terms - as a claim to property or dominion over the seas. The Canadian position on the status of arctic waters and the control of transit through them cannot be assessed as if it were no more than a claim to territorial sovereignty over an expanse of water. Canada's approach rests upon a perception of the unique nature of the area and the special needs to which that uniqueness gives rise, as well as an historical view of Canadian interests in the area.

The range of Canadian interests and concerns in respect of arctic waters can be divided into three categories: (a) issues relating to sovereignty, jurisdiction and security; (b) issues relating to environmental protection and the protection of northern communities; (c) issues relating to resource exploitation.

\section{Sovereignty, Jurisdiction and Security}

The view that Canada has, or ought to have, sovereignty over the waters of the Canadian arctic archipelago, as well as over the islands, has received frequent affirmation by Canadian political leaders, although not always without ambiguity. The waters have been variously described as part of "national terrain," as "internal waters," and as "Canadian waters." This desire for authority over northern waters accords to some extent with a Canadian self-image expressed by Prime Minister Diefenbaker in 1958 ("A Canada of the North . . . A new Vision! A new Hope! A soul for Canada," in Reid, 1974). But it would be a mistake to dismiss Canadian interests in sovereignty over arctic waters as notions grounded solely in an emotional view of the North. The continued emphasis upon "sovereignty" masks particular vital interests involved. The claim to sovereignty today rests upon a perceived need to administer the area in a way to protect particular Canadian interests, including the interests of the inhabitants of arctic areas and their environment, and to provide for the rational use of living and non-living resources of the waters of the Canadian Arctic.

Thus, the desire for jurisdiction over the waters of the Canadian arctic archipelago, of which the claim to sovereignty over the waters is a general expression, results from the perception that the use of these waters will have to be regulated because the consequences of their use will inevitably extend to the land masses and peoples of Canada. It is Canadian land that is most proximate to the waters of the arctic archipelago; it is Canadian people who use these waters and who often depend on them for their livelihood; and therefore, it is the land and its inhabitants that will bear the brunt of any harmful activities.

From a Canadian perspective, the legal regime that applies to the high seas does not provide appropriate guidance for management of the waters of the Canadian arctic archipelago. The consequences of any undertaking on the high seas are potentially shared by the community as a whole. Not so with the waters of the Canadian Arctic. The parallel with major international straits is also inadequate. Generally vessels remain within such straits only for relatively short periods of time, the hazards of navigating most international straits compare in no way with the hazards of navigating the waters of the Canadian arctic archipelago and the consequences of navigation do not usually extend only to a single state. In other words, the unique characteristics of the waters of the Canadian arctic archipelago make, in the Canadian view, the exercise of Canadian jurisdiction over them a matter of necessity. The most comprehensive basis for the exercise of such jurisdiction rests in a claim to sovereignty.

The question of security, although an ever-present factor in 19th-century claims to territorial sovereignty, has never been the dominant factor in Canadian claims to authority over arctic waters. There are several reasons for this. First, Canadian defence strategy in colonial times was focused in the east. Secondly, the nature of the area itself provided its own security; it was in a sense not capable of being defended, but by the same token it was not an area from which an attack could be readily mounted. Thirdly, when the issue of security in the North did become a major concern it was perceived as a need to counteract a buildup in the U.S. presence in the Canadian Arctic that had grown during the Second World War (Granatstein, 1976).

The Distant Early Warning (DEW) line controversy concerned Canadian sovereignty vis-à-vis the United States over northern lands, not the water. But the threat from the Soviet Union was perceived as a problem shared with the United States (or with the Western alliance) to be resolved through cooperative means. The interests of both Canada and the U.S. were best protected by such cooperation, and claims to sovereignty or to exercise sole jurisdiction over arctic waters for security purposes would have served no useful purpose for Canada (Sutherland, 1966; Gellner, 1976; Hockin and Brennan, 1976). However, it was a security-related issue - the voyage of the U.S.S. Nautilus under the polar ice cap in 1958 - that brought the question of jurisdiction over the waters to the fore, and the status of the waters of the Canadian arctic archipelago has been a recurrent issue in Canada-U.S. relations ever since. Equally, it was a security-related issue - the voyage of the Polar Sea in 1985 - that led to Canada's taking of a further step in its claim to the waters of the Canadian arctic archipelago with the drawing of straight baselines (Territorial Sea Geographical Co-ordinates (Area 7) Order, 1985).

Notwithstanding Canada's longstanding position on sovereignty over arctic waters, the claim had not until recently been embodied in any formal legislation. Legislation applicable to arctic management dealt with particular functional assertions of jurisdiction - the Canada Shipping Act, the Arctic Waters Pollution Prevention Act and the Canada Oil and Gas Act. Although Canada had established a 12-mile territorial sea, no basepoints had been designated to show how this was specifically applicable to arctic waters. On 1 January 1986, however, 
Canada closed any gaps that might previously have existed by promulgating straight baselines around the Canadian arctic archipelago and enclosing the waters within as the internal waters of Canada.

\section{Environmental Protection and the Protection of Northern Com- munities}

Canadian concerns about the environmental consequences of the use of the waters of the Canadian archipelago achieved considerable public prominence following the voyage of the Manhattan in 1969. Couching the problem posed by the Manhattan passage specifically in environmental terms seemed a logical approach. There was at that time a developing awareness worldwide of the deterioration of the human environment, particularly in relation to the oceans, and Sweden had already taken the initiative of placing the protection of the environment on the agenda of the United Nations General Assembly. This led ultimately to the Stockholm Conference in 1970.

One can, of course, debate whether Canada's environmental concerns in respect of the Arctic were developed as an alternative, less contentious, way of reinforcing Canadian sovereignty, or whether they were based on considered research into the environmental consequences of passage through arctic waters (Dosman, 1976; McConchie and Reid, 1977). Nevertheless, the approach struck a chord with the Canadian public, and this is reflected in the unanimous adoption of the Arctic Waters Pollution Prevention Act by the House of Commons, the development within Canada of a formal environmental review process for (inter alia) activities that affect northern waters, the development of public interest watchdogs for northern land and sea areas (pre-eminent among which is the Canadian Arctic Resources Committee, CARC) and a burgeoning of research in both the physical and social sciences relating to the use of arctic lands, waters and their resources and consequential environmental impacts. Whether concern for the arctic environment was a product of the Manhattan voyage or whether it has earlier antecedents, it is certainly now firmly entrenched in the Canadian view of the Arctic.

It is, however, misleading to interpret the Canadian concern for the protection of the arctic marine environment and the strength of the reaction that followed the Manhattan voyage as a desire to exclude shipping from arctic waters - to close off the Northwest Passage to foreign shipping, if not to all shipping. In 1970 Canada saw its interests as being served by the opening up of the Northwest Passage to shipping no less than the interests of the United States and other states would be served. The Canadian government at the time of the enactment of the arctic waters legislation stated that it was "determined to open up the Northwest Passage to safe navigation,' and the Arctic Waters Pollution Prevention Act provides for navigation of arctic waters, while establishing the conditions under which such navigation will take place. The submission of the Arctic Pilot Project to an Environmental Assessment Panel under the federal Environmental Assessment and Review Process (EARP) in 1973 was designed to determine the consequences of the proposal for the transport of liquefied natural gas (LNG) through arctic waters and to determine the special measures needed if the proposal proved feasible - it was not a rejection of the proposal in limine. Since 1970, however, serious questions have arisen in Canada about the consequences of opening the Northwest Passage to international maritime traffic.
Nevertheless, the approval by Canada of the pioneering tourist cruise of the Lindblad Explorer in the summer of 1984, and the cooperation extended to that voyage, is a further indication that the question is not whether marine transportation can be undertaken, but rather under what conditions such transportation is to take place. Some form of marine transportation in arctic waters is an inevitability; the problem is to find a way both to satisfy transportation needs and to ensure adequate protection of the arctic marine and land environments.

An aspect of environmental protection in arctic areas that has assumed a greater prominence over time is the preservation of the economic base, the way of life and the habitat of the indigenous people of the North. This has resulted from the rising political demands of the Inuit and the assertion of rights to land, waters and sea ice areas. Studies of the historical use by indigenous communities of the waters and sea ice (Vanderzwaag and Pharand, 1983) show a picture of use patterns over extensive areas of the arctic archipelago over the centuries. In particular, the Inuit Land Use and Occupancy Project has demonstrated that "the Inuit have hunted and trapped over a vast majority of the Northwest Passage." 'Dependence upon the area is both economic and cultural. Thus, the fact of marine transportation through arctic waters will have a direct impact on the lives of the inhabitants of the Arctic irrespective of whether marine casualties involving the release of harmful substances into the environment occur.

The importance of Inuit concerns to problems of arctic marine transportation has been characterized by the emerging political power and political institutions of the inhabitants of the North. Thus, Inuit opposition, including that of the Inuit Circumpolar Conference, which includes U.S. and Greenland as well as Canadian Inuit representation, was instrumental in effectively blocking the Arctic Pilot Project. This emergence of political power is reflected also in the process of devolution of authority from the federal government in Ottawa to institutions of the people of the North. This may lead to the formation of new territorial units, perhaps with provincial status. Although any constitutional change is unlikely to legally impair traditional federal responsibilities in the transportation, fisheries and energy fields, the processes of consultation that exist can only be intensified. The settlement of land claims and the continuing demand for direct involvement by formal institutions or less formal pressure groups in decision making will have important implications for the future of arctic marine transportation.

In the last 15 years knowledge of the nature of the arctic environment, the characteristics of the arctic ecosystem and the people who live there has increased. This knowledge contributes to a better understanding of the implications of arctic marine transportation, but at the same time it reinforces the Canadian view that Canada must have jurisdiction over arctic marine areas in order to ensure proper management, including the authority to manage the emerging need for marine transportation. From a Canadian perspective, subsequent knowledge has confirmed that the assertion of environmental jurisdiction in the Arctic Waters Pollution Prevention Act was essential, and subsequent reviews of that legislation have been concerned with an updating of technical standards. There has been no reconsideration of its basic thrust.

Since the 1970 legislation, which established a pollution zone 100 miles offshore, the Canada Shipping Act has been extended to apply up to 200 miles off the Canadian coast. Thus, north of $60^{\circ}$ the Arctic Waters Pollution Prevention Act applies up to 100 
miles from the coast and the pollution prevention provisions of the Canada Shipping Act apply between 100 and 200 miles offshore.

The outcry that followed the voyage of the Polar Sea in 1985 , however, showed that compliance in fact with environmental standards was not enough to satisfy the Canadian public. This led to the adoption on 1 January 1986 of the straight baseline method of measuring the starting point of the territorial sea. This was in effect a confirmation of Canada's claim that the waters of the arctic archipelago are the internal waters of Canada.

\section{Resource Exploitation Interests}

Canadian interests in the resources of arctic waters and the seabed predate the growth in environmental awareness. The Inuit interest in the living resources of the Arctic goes back to antiquity and continues today. "Interest," in fact, understates the condition - it is a relationship of economic, cultural and nutritional dependence. Canada's more general interest in the management of the living resources of arctic waters was manifested by the application of the Canadian 200-mile fishing zone to arctic waters by order-in-council in 1978 .

However, the discovery of oil at Prudhoe Bay by Atlantic Richfield in 1968 changed the dimension of resource interests in the Arctic. First, it served notice of the resource potential of northern areas (confirmed for Canada by later Dome Petroleum discoveries in the Beaufort Sea), and in the light of the 1973 oil crisis this potential loomed larger in Canada's resource calculations. Secondly, the discoveries, closely followed by the Manhattan test run, focused attention on the importance of the waters of the Northwest Passage as a maritime transportation route. Subsequent natural gas discoveries in the High Arctic focused attention again on the importance of arctic marine transportation. Since then, the Arctic Pilot Project for the transportation of LNG through arctic waters and Pan Arctic's "Bent Horn" proposal have required that the issues of arctic marine transportation be confronted directly.

The pressure to respond to proposals for resource extraction and removal in the Arctic brings to the fore the inevitable conflict, seen graphically in both Canada and the United States, between resource utilization and environmental controls and highlights the complexity of Canada's own arctic interests. The question is not whether environmental interests will win out over resource use or marine transportation interests in arctic waters, but rather under which legal regime such activities will take place and according to what standards.

\section{ALTERNATIVE REGIME MODELS: CANADIAN PERSPECTIVES}

Although one can conceive of a variety of different regimes for the management of arctic marine transportation, there are three basic models, of which others simply constitute variants. For the purposes of this paper it will be convenient to treat each model separately, in each case indicating to what extent it accords with Canadian interests and approaches. The three regimes can be characterized as (1) free and open use international management, (2) shared jurisdiction - cooperative management and (3) unilateral coastal state jurisdiction and management. Each model deals with a particular approach to both jurisdiction over the waters and management of marine transportation, because every management regime presupposes a particular jurisdictional status in the waters.

\section{Free and Open Use - International Management}

Under this approach the waters of the Arctic would be treated in a manner similar to the high seas. Each state would be free to use those waters according to its own needs, and shipping would be subject only to the jurisdiction of the flag state. No state would exercise sovereignty or jurisdiction over the waters. Standards imposed on users of those waters would have to be established in the traditional way - through customary development or through multilateral treaty. Standards established by treaty could not, of course, be applied against non-participating third states.

Such an approach poses immediate difficulties for arctic waters. Even in the absence of particular claims to historic waters or of the construction of baselines in the light of the particular geographic characteristics of the area, bands of coastal state jurisdiction would normally radiate from the islands of the Canadian arctic archipelago. These would include a 12 -mile territorial sea and a 200-mile fishing zone or exclusive economic zone. A 12-mile territorial sea measured from low-water mark (again disregarding the particular geographic characteristics of the area) would result in the enclosure of Barrow Strait as well as Prince of Wales Strait (the so called "gateways") (Pharand, 1973) within the territorial seas of Canada. The Northwest Passage would, therefore, go through part of the territorial waters of Canada, and thus the "free and open" regime would not apply throughout its full extent. Even if an international straits regime were established, passage would not be entirely "free and open."

Moreover, even in the other waters of the Passage a free and open regime could not be applied without qualification. The whole of the area is within 200 miles of Canadian coasts and would thus fall within any Canadian exclusive economic zone. This means that fisheries, continental shelf and marine scientific research would all be within the jurisdiction of Canada, and as the coastal state Canada would have certain rights in respect of the prevention of marine pollution and would to a limited extent have some controls over shipping.

Objections such as these are often perceived as legalistic. But the rules relating to the territorial sea and the exclusive economic zone (EEZ) rests upon a recognition of the primary interest of the coastal state in activities off its coasts. That primary interest is a consequence of the political and economic relationship of the land to the adjacent marine areas. The foundation of the doctrine of the territorial sea lies in the security needs of the coastal state, and the foundations of the continental shelf and the exclusive economic zone lie in the economic interests and needs of the coastal state. Thus the adoption of a complete free and open use regime for arctic waters would be contrary to the contemporary trend in the law of the sea and, in fact, it would be inconsistent with the actual practices of both Canada and the U.S. It would correspond to neither jurisdictional nor management needs in respect of arctic waters.

\section{Shared Jurisdiction - Cooperative Management}

This approach would involve submitting arctic waters to a regime established by the arctic coastal states themselves either bilaterally, involving Canada and the United States alone, or regionally, involving all the arctic coastal states. The idea that the arctic littoral states should assert joint jurisdiction over arctic waters and assume joint responsibility for the management of them is similar to the claims made by states surrounding 
enclosed or semi-enclosed seas. Article 123 of the 1982 Law of the Sea Convention provides that states bordering enclosed or semi-enclosed seas should cooperate, specifically:

(i) to co-ordinate the management, conservation, exploration and exploitation of the living resources of the sea;

(ii) to co-ordinate the implementation of their rights and duties with respect to the protection and preservation of the marine environment;

(iii) to co-ordinate their scientific research policies and undertake where appropriate programmes of scientific research in the area.

The treatment of the Arctic Ocean as a whole as an enclosed or semi-enclosed sea would be an expansive application of the concept of enclosure, and it is difficult to see that a reasonable construction of the words "enclosed or semi-enclosed" would admit of such a characterization. Nevertheless, the principle underlying the rules relating to enclosed or semi-enclosed seas - that it is the littoral states who are primarily affected by the use of those seas, and thus they should have the principle, if not exclusive, responsibility for management and control - does provide some analogy for approaches to the management of arctic waters and in particular the management of arctic marine transportation.

There are a variety of models throughout the world of regional management regimes, such as international fisheries commissions (Koers, 1973), and regional bodies concerned with marine pollution. The common features of these institutions is that their member states collaborate to establish the scientific basis on which decisions about resource utilization or the control of certain kinds of uses are made. Then, on the basis of common discussions, decisions are made through a consensus or majority decision-making procedure. These decisions may be in the form of recommendations to member states or, as in the case of some fisheries commissions, the decision may constitute an agreed allocation of the catch binding upon the member state.

The paradigm for bilateral cooperative arrangements between Canada and the United States is the International Joint Commission (IJC). Since its establishment under the Boundary Waters Treaty of 1909, the commission has been involved in investigating the effects of activities on boundary waters, regulating certain uses of those waters and reporting to the two governments on specific matters referred to it. Although it has dispute settlement responsibilities under its constitution, no request has ever been made for the IJC to exercise arbitral or judicial functions. The ability of the IJC to function effectively is constrained by the support that the national governments of the time are prepared to provide; nevertheless, it has established a record of independence and impartiality that offers a model for bilateral management in other areas (Bloomfield and Fitzgerald, 1958).

How appropriate, then, are institutions such as the IJC for the management of arctic marine transportation? Seen from a Canadian perspective, there are several difficulties. First, the chances of establishing a regional management regime that would include the Soviet Union appear remote. It would entail a renunciation by the Soviet Union of its position on the status of the waters of the eastern Arctic and a willingness to submit those waters to joint management. Bilateral Canada-U.S. management (perhaps involving Denmark as well) might, therefore, provide the only possibility for shared management. Secondly, a precondition for an effective cooperative management regime is a comparability of interest in the participating states. Existing regimes are of two types. First, the participating states may be dealing with an area or resource over which no state exercises jurisdiction, but in which all of the states have a common interest. This is so of the international fisheries commissions, which have historically operated in areas beyond national jurisdiction. Secondly, the participating states may be involved in the regulation of matters within the national jurisdiction of each because they have recognized that they have a common problem that should be dealt with through cooperation with neighbouring states. This applies to the IJC and bodies such as the International Commission for the Rhine.

But the position in respect of the waters of the Canadian arctic archipelago is different. Putting aside the question of any Canadian claim to treat these waters as internal, the waters could not be regarded just (if at all) as high seas. The waters of the Northwest Passage are at the very least within the domains of the exclusive economic zone of Canada. Thus, at the outset there is an imbalance of interest between Canada and other states in those waters. The interest of other states is primarily in the use of the waters for transit. Canada is certainly interested in transit uses, but it is also interested in the living resources of those waters, in the resources of the seabed and in the protection of the surrounding marine and land environments. There is not, therefore, the equality of interest in a common resource that exists in the case of international fisheries commissions.

The IJC also operates in a specific jurisdictional context. It deals with problems common to Canada and the United States, the solutions to which are applied by each state in areas of recognized separate jurisdiction. Each state retains its territorial jurisdiction over its boundary waters and applies the results of the work of the IJC through its own domestic law.

The problem cannot be avoided by establishing a joint management regime unless the question of jurisdiction is resolved. A joint management regime over an area in which the jurisdiction of no single state is acknowledged implies that it is an area of joint jurisdiction (otherwise regulations could not be enforced against third states). Thus, a joint management regime between Canada and the U.S. in respect of arctic waters, or in particular in respect of the waters of the Northwest Passage, would (unless applied only to the flag vessels of the two states) constitute, in effect, a joint claim to jurisdiction over those waters. Thus, from a Canadian perspective a joint or shared management system without an acknowledgement of Canadian jurisdiction over the waters of the Northwest Passage would constitute a renunciation of Canadian claims in favour of a joint regime of jurisdiction in an area where Canadian interests are greater, more varied and have a stronger claim for recognition under international law. The legal basis for a regime of joint jurisdiction, whether claimed expressly or arising as a result of a claim to joint management of the area, would rest on the same basis as the Canadian claim to sole jurisdiction over the area. In these circumstances it is difficult to see why it would be in the Canadian interest to agree to a cooperative management regime that carried with it a regime of joint jurisdiction.

\section{Unilateral Coastal State Jurisdiction and Management}

This approach is embodied in the sector theory; each arctic sector state is entitled to jurisdiction over, and therefore to manage on its own, the waters that extend from its coasts to the North Pole. Each arctic sector would be subject to the exclusive 
jurisdiction of an individual state, and thus all the waters of the Arctic would be "internal waters." However, it would be difficult to justify in law the enclosure of the whole of the Arctic Ocean in this way, even if all of the arctic states were to agree to treat the area as an enclosed sea. On the other hand, a basis for treating some of the arctic waters as internal waters can be found where the circumstances are such that an historic title can be maintained or where the use of straight baselines for the measurement of the territorial sea is permitted. Although the sector theory is often still associated with Canadian sovereignty claims in the North, in fact those claims find a better basis in the geographical nature of the arctic archipelago in the interrelationship of land and water that stretches from continental Canada to the North Pole and in historical factors.

Obviously, unilateral coastal state jurisdiction and management has many attractions for Canada, for it would ensure that the management of arctic waters and of transportation through those waters was retained in Canadian hands. Accordingly, it would ensure that Canadian interests and concerns were taken fully into account in the design of any regime to manage arctic marine transportation.

Such an approach may offer less to the United States within its own zone because of the relatively open nature of the arctic waters off Alaska and the lack of islands extending from the coast northward. The existing regime of the law of the sea governing maritime transit (as set out in the 1982 Convention on the Law of the Sea) would be applicable to the areas of territorial sea, exclusive economic zone and high seas respectively (subject to the applicability of Article 234 of the Convention, which will be discussed below).

Notwithstanding the apparent advantages of a model of unilateral coastal state jurisdiction and management, a management regime cannot operate in complete isolation. Ships other than those flying the flag of the coastal state will wish to transit arctic waters, and thus their interests will have to be considered. Moreover, there are immense practical disadvantages in establishing shipping standards substantially different from those established by other arctic littoral states. In other words, there would have to be cooperation between arctic littoral states on the formulation of standards even if ultimately the adoption of those standards and their application falls to each state within its own waters. Cooperation is essential, too, with major transit users of the waters. In practice, therefore, a regime of unilateral coastal state jurisdiction might be combined with a cooperative management regime. The locus of ultimate authority to legislate and to enforce would remain with the state that has jurisdiction, but the nature of the management regime would depend upon the modalities of cooperation worked out in each case.

\section{FUNDAMENTAL ISSUES: APPROPRIATE REGIMES}

The above discussion has dealt with management regimes in general terms. The question now becomes whether the particular interests involved in arctic marine transportation require one type of regime rather than another.

\section{Security Issues}

The question of security is in certain respects distinct from the problems associated with the development of a regime for arctic marine transportation. Moreover, it is a matter on which Canada-U.S. cooperation is long-standing. Mechanisms for cooperation between Canada and the U.S. on defence are well established, and problems associated with the use of arctic waters by military vessels might be best dealt with within those mechanisms.

Nevertheless, some of the problems to which military uses give rise are similar to the problems raised by potential commercial navigation in arctic waters, such as the submerged or non-submerged transit of submarines and the passage of nuclearpowered vessels. Thus, although there are some matters that can be resolved in the light of the exigencies of defence considerations in arctic waters, there are others whose solution must be in conformity with any regime for commercial marine transportation. Passage by U.S. naval vessels through Canadian internal waters has been accommodated from time to time through Canada-U.S. cooperation, and thus many defence needs can be worked out through traditional cooperative channels between Canada and the U.S. On this issue, however, the U.S. position in 1985 at the time of the voyage of the Polar Sea appeared to be quite ambiguous, yet it is a matter on which the United States has a particular interest in ensuring Canadian cooperation.

\section{Resource Exploitation}

The management of resource exploitation in arctic waters (including the seabed) is not directly in issue when considering the development of a regime for marine arctic transportation. On the basis of the 1982 Convention on the Law of the Sea the jurisdictional regime for resource exploration and exploitation is relatively clear - a 200 -mile exclusive economic zone and sovereign rights over the resources of the continental shelf out to the outer edge of the continental margin. Problems exist in the delimitation of the maritime boundary in the Beaufort Sea, both for fisheries and continental shelf purposes, and the precise location of the outer limit of the continental shelf has yet to be determined (including the question of the status of the Alpha Ridge). Resource exploitation issues do not of themselves pose problems of joint management, apart from the question of transboundary fishery stocks or transboundary hydrocarbon or other mineral deposits.

There are several matters, nevertheless, on which interests are common and cooperation seems logical. First, there is the need for resource-related scientific investigations of arctic waters and ice areas. Mechanisms already existing for the approval of scientific research in the waters off other coasts of the two states would, prima facie, be applied to marine scientific research in arctic waters, subject to whatever special standards may be necessary for scientific research vessels operating in arctic waters. Second, the development of technology for hydrocarbon exploitation in arctic areas is a problem common to both Canada and the United States. Related matters such as the environmental effects of exploitation and the relationship of oil drilling structures to potential shipping routes require joint attention. At this level cooperation in sharing expertise and developing common standards will be essential. Again, however, the purpose of such cooperation is to assist each state in developing a regime applicable to an area subject to its own jurisdiction. No regime of joint jurisdiction or management (except perhaps in respect of overlapping stocks or deposits in boundary areas) is necessary.

Third, the issue arising out of resource exploitation in arctic waters with the most important implications for arctic marine transportation is the removal of the resource from the site to markets. Assuming that the debate over the utility of pipelines 
as opposed to shipping will not be resolved against shipping completely, one comes back to the central question of the development of a regime for management and control of the shipping of these resources. Resource exploitation interests of themselves do not dictate any particular type of management regime for arctic waters. Nevertheless, regardless of the precise status of the waters for marine transportation purposes, for resource exploitation purposes the waters fall within Canadian jurisdiction.

\section{Environmental Protection}

Environmental protection has been the central concern in Canadian approaches to the uses of arctic waters. The problem of environmental protection can be reduced to a series of particular questions: (1) What is it that requires protection? Whose interests are at stake? (2) What activities are likely to cause harm? (3) What standards are necessary to ensure adequate protection? (4) Who should set those standards, administer and enforce them?

The first two questions relate to research and inquiry into the characteristics of the arctic environment and of the activities likely to affect that environment - in other words, the development of an adequate database. On these matters cooperation between Canada and the U.S. exists, and it can be strengthened without infringing upon the particular interests of either state. The third question, concerned with determining appropriate standards, is also a matter that should be resolved through cooperation and consultation between the states involved. Standard-setting involves a reconciliation of the interests of states wishing to use arctic waters for marine transportation purposes and Canadian interests in preserving the ecology of the water and land of the arctic archipelago. Ultimately, however, this is related to the fourth question - who, in the last resort, has the authority to set the standards and to administer and enforce them? Obviously there can be disagreement over what standards are necessary - arising out of disagreement over the likelihood of harm resulting from any particular activity - and, therefore, it becomes a matter of importance who finally can decide which standards will be adopted.

From a Canadian perspective a free and open use regime under which standards are established by international agreement is not adequate for arctic waters. The effect of multilateral decision making in respect of the management of arctic marine transportation is to submerge the interests of the single state whose adjacent land and waters are likely to be affected by that transportation to the interests of the many. Navigation interests will always override environmental and other interests. That, in the Canadian view, has been the defect in the Grotian doctrine of freedom of the seas, which the 1982 Convention on the Law of the Sea went some way to remedying - in particular, in relation to the Arctic, by Article 234.

By the same token, a cooperative management regime that in the absence of consensus can only fall back on the status quo has similar disadvantages. If the status quo favours transit over environmental interests (as the law of the sea traditionally has done), then again the particular interests of the state whose adjacent waters and land are most likely to be affected by marine transit are put in second place. On the other hand, cooperative management mechanisms built upon a foundation where ultimately the exercise of jurisdiction is the responsibility of the state most affected offers much more promise. This does not mean that environmental interests will always dominate navigation or transportation interests; the way in which these interests are reconciled will depend upon the way the regime set up to balance them carries out its task. It is the function of a cooperative management regime in this context to ensure that all interests are taken into account, and not just the interests of the state in which jurisdiction ultimately rests.

\section{Navigation in Arctic Waters}

The various possible legal regimes for the control of arctic waters have been discussed frequently, and it will suffice here only to outline them. It is, in fact, only the waters of the Canadian arctic archipelago that pose difficulty. Beyond the archipelago the normal regimes of internal waters, territorial sea and exclusive economic zone apply (subject to the applicability of Article 234 of the 1982 Law of the Sea Convention).

The United States has maintained in the past that the waters of the Northwest Passage constitute an international strait, through which innocent passage cannot be suspended. Under this view, all ships transitting the Northwest Passage are subject only to the law of their flag state, which would apply any internationally agreed standards. Canada, by contrast, has maintained the right, either by historic title or otherwise, to treat the waters of the Canadian arctic archipelago as the internal waters of Canada. Under such a regime Canada would have the right to regulate all shipping within those waters, including setting minimum requirements for ships seeking access to the waters or prohibiting access altogether. Thus, no right of passage would exist in those waters unless authorized by Canada, and the waters would not constitute an international strait.

An alternative approach to regulating shipping, which put aside but was not intended to prejudice Canada's claim to treat these waters as internal waters, was adopted in the Arctic Waters Pollution Prevention Act. There Canada asserted the authority to set standards for all shipping, including standards relating to the construction, design, manning and equipment of vessels, in arctic waters. This authority was said to derive from the special interest and responsibility of the adjacent coastal state in protecting the unique ecology of the arctic environment and was not based explicitly on any claim to historic title over the waters. This approach, although highly controversial at the time, is now embodied in Article 234 of the 1982 Convention on the Law of the Sea, which authorizes coastal states to adopt and enforce non-discriminatory laws for the prevention, reduction and control of marine pollution in ice-covered areas within the limits of the EEZ " where particularly severe climatic conditions and the presence of ice covering such areas for most of the year create obstructions or exceptional hazards to navigation, and pollution of the marine environment could cause major harm to or irreversible disturbance of the ecological balance.' In essence, the provision recognizes the predominant interest and responsibility of the adjacent coastal state and thus allows it to enact and enforce laws relating to shipping designed to protect the particular marine and land environments of ice-covered ocean areas.

Canada has consistently indicated its opposition to the characterization of the Northwest Passage as an international strait. Although it is difficult to deny that the Passage is a strait in geographic terms, in view of the fact that the Northwest Passage has not been used for international navigation in a legal sense, the argument that at present it constitutes an international strait 
has little foundation in law. On the other hand, the passage of the arctic waters legislation and the negotiation of Article 234 of the 1982 Convention on the Law of the Sea were endeavours to try to secure domestically and to obtain international recognition for the necessary authority to enable Canada to control shipping in arctic waters without unduly interfering with the interests of other states.

The question must be asked, therefore, whether Article 234 is an adequate basis for jurisdiction - should it be used as a starting point for the construction of a regime for marine transportation in arctic waters? Of course, the status of Article 234 will always remain in doubt until the Law of the Sea Convention comes into force, and even then failure by the U.S. to become a party to that Convention would make Article 234 a tenuous basis for the erection of a Canadian jurisdictional regime. In this regard, it is significant that President Reagan's proclamation of a 200-mile EEZ on 10 March 1983 made no reference to any regime for arctic waters and thus has left open where the U.S. stands on the acceptability or otherwise of the Article 234 regime.

These considerations apart, Article 234 raises problems of interpretation that would have to be resolved before it could be regarded as a satisfactory basis for a legal regime. One would wish to know, for example, whether Article 234 applies to all waters seaward of the outer limit of the 200-mile EEZ, or only to the waters of the EEZ itself (i.e., does it apply to the territorial sea?) and whether Article 234 applies to all of the waters of the Canadian arctic archipelago, thus excluding the regime of international straits from the Northwest Passage (McRae and Goundrey, 1982). An interpretation of Article 234 that would allow the coastal state to establish design, construction, manning and equipment standards as it deemed appropriate for arctic waters within 200 miles of its coasts would correspond with the jurisdiction asserted by Canada in the Arctic Waters Pollution Prevention Act. The requirement of Article 234 that due regard must be had to navigation poses no real difficulty in view of Canada's expressed interest in opening the waters of the Northwest Passage to navigation and in view of the fact that the arctic waters legislation, while proscribing navigation that could result in damage to the environment, does not purport to prohibit navigation altogether. On the other hand, a more restrictive interpretation of Article 234 would make it, in Canadian eyes, a less effective means for securing Canada's interests in the waters of the arctic archipelago.

An argument sometimes invoked by the United States against an assertion of jurisdiction by Canada over the waters of the arctic archipelago is that it would create a bad precedent that might be followed by other states in other areas and under different conditions. From a Canadian perspective this argument does not go to the merits of the question of jurisdiction over arctic waters and hardly appears as a sufficient justification for the U.S. position. The intent of Article 234 was to acknowledge that ice-covered areas are unique, and the separate inclusion of that provision in the 1982 Convention on the Law of the Sea represented a recognition by states of the unique characteristics of these waters. The U.S. position might have been a reasonable one during the course of negotiations when the U.S. was seeking to limit claims to extensive coastal state jurisdiction, but the position appears less defensible now that negotiations have concluded and claims to jurisdiction are crystallized.

Moreover, the logic of the U.S. argument would also suggest that the United States must disapprove of a cooperative manage- ment regime based upon joint jurisdiction over the area, because such a regime involves an exercise of authority by a small number of states over waters otherwise open to all. This is precisely the unfavourable precedent perceived by the United States. It might be noted, however, that the U.S. action in refusing to sign the 1982 Convention on the Law of the Sea may have the result that the U.S. will have to engage in bilateral negotiations with "straits states" to secure rights of passage that it could have obtained through the Convention. If the United States is prepared to negotiate such special regimes and thereby recognize the special interests of straits states, a "special regime" for the waters of the Canadian arctic archipelago should not be considered objectionable.

There is no doubt that transit interests on their own are best served by a regime of free and open passage; under such a regime transit interests are paramount. When, however, other factors, such as environmental protection, also have to be considered, then a system under which authority ultimately resides in the flag state is defective. Cooperative management regimes where jurisdiction is shared can provide a better mechanism, provided that the interests of the states involved are common and relatively equally balanced. From a Canadian perspective this balance does not exist in relation to the waters of the arctic archipelago. Canada and the United States share potential transit interests in those waters; they do not share environmental interests to the same degree. On the other hand, a system of shared management for Canadian and U.S. arctic waters based upon recognition of Canadian sovereignty over the waters of the arctic archipelago could be the basis for an effective cooperative management regime for arctic marine transportation.

\section{A MANAGEMENT REGIME}

An effective management regime for arctic marine transportation could be worked out only if the question of jurisdiction over the waters of the Canadian arctic archipelago is resolved. In essence, this requires the acceptance by the United States of Canadian authority to enact and enforce laws designed to regulate shipping in those waters in terms similar to those set out in the Arctic Waters Pollution Prevention Act. This could be done either by an acceptance of Canadian sovereignty or by putting Canadian sovereignty to one side and acknowledging an interpretation of the Article 234 regime, under which the Northwest Passage could not in law become an international strait. The adoption by Canada of straight baselines for the Canadian arctic archipelago complicates matters, but it does not prevent the United States from acknowledging the full extent of environmental jurisdiction of the coastal state as embodied in Article 234. An essential element of this, from a Canadian perspective, would be recognition that the jurisdiction embodied in the Arctic Waters Pollution Prevention Act is fully consistent with Article 234.

This would provide the starting point for the negotiation of a regime for arctic marine transportation. Again, it should be emphasized that the fact that exclusive Canadian jurisdiction existed over all of the waters of the arctic archipelago would not mean the exclusion of all vessels from those waters. There are several examples of waters subject to exclusive Canadian jurisdiction through which U.S. vessels have been accorded a right of transit. Under the terms of the 1846 Treaty of Washington 
(Article XXVI), Canada and the United States each grant to the other free and open passage through the waters on its own side of the Strait of Juan de Fuca. U.S. vessels travel through those parts of the St. Lawrence River that are wholly within Canadian territory by agreement with Canada. Thus, rights of navigation through arctic waters could be established by agreement in advance and not depend on approval in individual cases or for short-term periods. This would allay concerns that transit may at any time be arbitrarily denied.

The conditions under which such transit could be granted would be subject to negotiation. Obviously, it would defeat the purpose of Canada's environmental regulations if passage were guaranteed without attaching conditions relating to the standards that must be met by vessels in respect of design, construction, manning and operation. But this, too, should be submitted to a process of negotiation. Moreover, a transit agreement of this kind would, presumably, have to be long term and provide mechanisms to ensure that changes in regulations were made after a process of consultations - perhaps as the result of a recommendation by a joint consultative mechanism.

Such an approach, therefore, envisages a form of cooperative management under which both countries would cooperate in various phases of the management process. That process would include the assembly of the relevant data, the determination of the appropriate standards and their embodiment in suitable legislation or regulations and the administration and enforcement of those regulations. In so far as the regime would be designed to preserve the environment, it will require a process for monitoring environmental impacts. Specific cooperative institutions might be created, such as joint commissions, cooperative research programs, regular meetings of officials at the relevant departmental levels and occasional conferences to assess progress. Access to any joint intergovernmental body should be provided to interested groups, in particular groups representing northern communities.

There are also a variety of navigation-related matters that would have to be dealt with in any management regime for marine transportation in arctic waters. These include the provision of assistance to navigation in the form of navigational aids, pilotage services, icebreaker support, search and rescue, salvage facilities and clean-up facilities in the eventuality of marine casualties. In some of these matters cooperation already exists (e.g., Canada-U.S. Joint Marine Pollution Contingency Plan), and in principle such cooperation can be developed through close coordination at departmental levels and through regular intergovernmental consultations.

The possible institutional forms for a management regime would vary, depending upon the areas of cooperation and upon the extent to which the governments might be prepared to delegate authority. The IJC, referred to already, offers a potential model, although it might be queried whether governments of today would show such a willingness to assign decision-making powers to quasi-independent bodies. At the very least, however, the institutional structure would require a forum for scientific collaboration in research, monitoring and evaluation; a regular forum for evaluation of standards, the recommendation of revisions to existing standards and the formulation of new standards; and a mechanism for consultation with interested and affected groups. In addition, there would have to be a body to oversee operational relationships in respect of oil spills or other marine casualty contingency plans, icebreaker support, etc.

\section{CONCLUSIONS}

Canadian interests in relation to a marine transportation regime for arctic waters flow more or less directly from geography, and because the geography of the Canadian Arctic differs from the geography of the-U.S. Arctic, interests inevitably differ. The distinguishing geographic characteristic of the Canadian Arctic is the archipelago, with its myriad of islands and waterways. Marine traffic must take a route between these islands, with the result that the consequences of marine transportation will extend to them, to their inhabitants and to the marine and land environment.

The particular interest and the type of authority asserted by Canada in respect of arctic waters finds a parallel in the general trend of the new law of the sea. The principle underlying the extension of coastal state jurisdiction to a 200 -mile exclusive economic zone is that responsibility for managing resources flows from contiguity. It is the proximity of the waters of the arctic archipelago to the islands of the archipelago in combination with the specific characteristics of the arctic environment that provides the rationale for Canadian assertions of sovereignty and jurisdiction over the waters of the Canadian arctic archipelago.

Various regimes can be devised to manage marine transportation in arctic waters, but each presupposes a particular view of the legal status of those waters. Attempts to devise regimes that ignore the question of legal status can succeed only if a particular view of the status of those waters is assumed. Thus, a resolution of the status of the waters is a precondition to the development of a successful management regime.

Recognition that the waters of the Northwest Passage fall within Canadian jurisdiction does not foreclose the development of cooperative regimes between Canada and the United States. Rather, it would provide a starting point for the creation of a regime under which passage through the waters of the Canadian Arctic could be guaranteed to vessels of the United States in accordance with conditions that would ensure adequate protection of the arctic environment without undue interference with legitimate navigation needs. A cooperative regime under these conditions would ensure that all relevant interests are taken into account in the setting of appropriate standards and their implementation. Mechanisms for cooperation in the process of transit management in arctic waters could involve such matters as arctic research, standard setting, aids and assistance to navigation, search and rescue, monitoring environmental impacts and enforcement.

\section{REFERENCES}

BLOOMFIELD, L.M., and FITZGERALD, G.F. 1958. Boundary Waters Problems of Canada and the United States. Toronto: Carswell. 264 p.

DOSMAN, E.J. 1976. The northern sovereignty crisis 1968-70. In: Dosman, E.J., ed. The Arctic in Question. Toronto: Oxford University Press. 34-57.

GELLNER, J. 1976. The military task: sovereignty and security, surveillance and control in the far north. In: Dosman, E.J., ed. The Arctic in Question. Toronto: Oxford University Press. 85-101.

GRANATSTEIN, J.L. 1976. A fit of absence of mind: Canada's national interest in the north to 1968. In: Dosman, E.J., ed. The Arctic in Question. Toronto: Oxford University Press. 13-33.

HOCKIN, T.A, and BRENNAN, P.A. 1976. Canada's arctic and its strategic importance. In: Dosman, E.J., ed. The Arctic in Question. Toronto: Oxford University Press. 102-120.

KOERS, A.W. 1973. International Regulation of Marine Fisheries: A Study of Regional Fisheries Organizations. Surrey: Fishing News (Books) Ltd. 368 p. 
MCCONCHIE, R.D., and REID, R.S. 1977. Canadian foreign policy and International Straits. In: Johnson, B., and Zacher, M.W., eds. Canadian Foreign Policy and the Law of the Sea. Vancouver: University of British Columbia Press. 158-201.

MCRAE, D.M., and GOUNDREY, D.J. 1982. Environmental jurisdiction in arctic waters: The extent of article 234. University of British Columbia Law Review 16:197-228.

PHARAND, D. 1973. The Law of the Sea of the Arctic. Ottawa: University of Ottawa Press. $367 \mathrm{p}$

REID, R.S. 1974. The Canadian claim to sovereignty over the waters of the arctic. Canadian Yearbook of International Law 12:111-136.
SUTHERLAND, R.J. 1966. The strategic significance of the Canadian arctic. In: Macdonald, R. St. J., ed. The Arctic Frontier. Toronto: University of Toronto Press. 256-278.

TERRITORIAL SEA GEOGRAPHICAL CO-ORDINATES (AREA 7) ORDER, Privy Council 1985-2739, 10 September 1985.

VANDERZWAAG, D., and PHARAND, D. 1983. Inuit and the ice: Implications for Canadian arctic waters. Canadian Yearbook of International Law 21:53-84. 